\title{
PEMBERDAYAAN PENDAMPING PROGRAM PERILAKU HIDUP BERSIH DAN SEHAT (PHBS) ANAK USIA DINI DALAM PEMANFAATAN LIDAH BUAYA (ALOE VERA) SEBAGAI UPAYA PREVENTIF MENGHADAPI PANDEMI COVID-19 MELALUI PEMBUATAN HANDWASHING FOAMING DI PAUD CERDAS CERIA DI DESA PANDANSARI KEC.PONCOKUSUMO
}

\author{
Monika Luhung1), Sr.Felisitas A.Sri S Misc ${ }^{1)}$ \\ 1)Program Studi D3 Keperawatan, STIKes Panti Waluya Malang, Malang, Jawa Timur, Indonesia \\ Corresponding author : Monika Luhung \\ Email : monikaluhung@gmail.com
}

Diterim 2021, Direvisi 2021, Disetujui 2021

\begin{abstract}
ABSTRAK
PAUD Cerdas Ceria berada di Desa Pandansari merupakan salah satu desa yang yang terletak di Kecamatan Poncokusumo, Kabupaten Malang. Dalam kegiatan pembelajaran didamping oleh 4 tenaga dari PAUD Cerdas Ceria serta dibantu oleh ibu-ibu dari wali siswa PAUD tersebut. Adapun tingkat pendidikan ibu-ibu dari wali siswa tersebut memiliki latar belakang pendidikan lulus SD dan SLTP sehingga masih diperlukan edukasi dan informasi terbarukan di segala bidang sebagai upaya peningkatan kesehatan masyarakat. Berdasarkan wawancara kepada maupun ibu-ibu wali siswa banyak siswa yang belum terbiasa dengan PHBS salah satunya aktifitas mencuci tagan yang baik dan benar. Tujuan dari kegiatan ini adalah peningkatan perilaku hidup bersih dan sehat sebagai salah satu preventif dalam memutus rantai penyebaran berbagai penyakit termasuk Covid-19.

Kegiatan ini telah terlaksana selama bulan Juli 2021 dengan metode dalam jaringan (daring) dengan menggunakan sosial media. Dari 45 pendamping yang hadir ditemukan 27 atau $60 \%$ pendamping yang masih belum tepat dalam melakukan aktifitas cuci tangan dengan baik dan benar. Sedangkan dalam proses pembuatan sabun cuci tangan dengan memanfaatkan lidah buaya sebanyak 38 atau $84 \%$ pendamping telah dapat membuat dengan baik dan benar. Secara keseluruhan kegiatan berjalan lancar serta antusiasme pendamping sangat baik

Ivities
\end{abstract}

Kata Kunci : cuci tangan; PAUD; pendamping; sabun cuci

\begin{abstract}
Smart Ceria PAUD located in Pandansari Village is one of the villages located in Poncokusumo District, Malang Regency. In the learning activities accompanied by 4 staff from the Smart Ceria PAUD and assited by the mothers of the PAUD student'e guadians, the have an educational background of graduating from elementary and junior high school so that education and updated information are still needed in all fields as an effort to improve public health. Based on interviews with students and their guardians, many students are not familiar with PHBS, one of which is good and correct hand washing activities. The purpose of this activity is to increase clean and healthy living behavior as a preventive measure in breaking the chain of spread of various diseases including the covid 19 virus. This activity has been carried out during July 2021 with an online method using social media. Of the 45 companions who were present, 27 or $60 \%$ of the companions were found who were still not right in carrying out handwashing activities properly and correctly. Meanwhile, in the process of making hand soap using aloe vera , 38 or $84 \%$ of the companions have been able to make it properly and correctly. Overall the activity went smoothly and the enthusism of the companion was very good.
\end{abstract}

Keywords: wash hand; PAUD; companion; hand soap

\section{PENDAHULUAN}

Desa Pandansari berada di sebelah selatan Gunung Bromo. Secara geografis termasuk dalam kawasan Taman Nasional Bromo Tengger Semeru (TNBTS) yang sangat kaya akan potensi sumberdaya alam hayati. Mata pencaharian utama penduduk desa
Pandansari adalah bertani dan ada pula yang berdagang dan beternak ayam. Komoditas utamanya adalah tanaman buah apel, sebagian juga ada kelengkeng dan tanaman semusim yaitu sayuran Untuk tingkat pendidikan berdasarkan data pada tahun 2018 adalah sebagai berikut : 
Tabel 1 :Tingkat pendidikan

\begin{tabular}{ccc}
\hline $\begin{array}{c}\text { Tidak } \\
\text { sekolah }\end{array}$ & $:$ & 762 orang \\
\hline Lulus SD & $:$ & 3.752 orang \\
\hline Lulus & $:$ & 676 orang \\
SLTP & & \\
\hline Lulus & $:$ & 152 orang \\
SLTA & & \\
\hline Sarjana & $:$ & 51 orang \\
\hline
\end{tabular}

Berdasarkan data Tabel 1 diatas maka dapat diketahui bahwa sebagian besar para orang tua yang tinggal di desa Pandansari Kecamatan Poncokusumo masih banyak yang berlatar belakang lulusan Sekolah Dasar (SD). Sehingga masih diperlukan edukasi dan informasi yang terbarukan di segala bidang untuk peningkatan pemahanan masyarakat khususnya pada peningkatan derajat kesehatan. Sedangkan untuk fasilitas pendidikan jenjang pra dasar sejauh ini di desa Pandansari Kecamatan Poncokusumo masih memiliki Taman Kanak-Kanak sejumlah empat sekolah. Perlu diketahui siswa Taman KanakKanak tergolong anak usia dini.

Untuk perilaku hidup bersih dan sehat berdasarkan hasil penelitian dan riset masih cukup banyak penduduk yang belum menerapkan secara maksimal, walaupun ada kecenderungan perbaikan. Berdasarkan analisis kecenderungan secara rerata nasional terdapat peningkatan proporsi penduduk berperilaku cuci tangan yang benar pada tahun 2018 yaitu 47,0\% dibandingkan tahun 2013 yaitu $23,2 \%$. Demikian pula perilaku BAB terjadi peningkatan dari $71,1 \%$ pada tahun 2013 menjadi $82,6 \%$ pada tahun 2018 . Untuk perilaku benar dalam mencuci tangan berkaitan dengan faktor gender, ekonomi, dan daerah tempat tinggal ditemukan sebagian besar penduduk Indonesia khususnya anak usia dini mencuci tangan pada saat mandi pagi maupun mandi sore $76,6 \%$. Mencuci tangan yang benar antara lain pada waktu sebelum \& sesudah makan pagi,siang serta malam, setelah dari toilet, sewaktu mandi, setelah bersin \& batuk, setelah pakai gadget/benda elektronik lainnya serta setelah menyentuh sampah (Center for Disease Control and Preventif 2019). Serta pelu diketahui bahwasannya untuk mencuci tangan dengan benar baik secara teknis dan waktu ini untuk Indonesia ditemukan hanya 8,5\%

Berdasarkan observasi dalam bentuk wawancara kepada 2 orang pendidik dan kurang lebih 20 anak beserta orang tuanya di PAUD Cerdas Ceria di Desa Pandansari Kec. Poncokusumo banyak anak yang belum terbiasa dengan PHBS yang salah satunya yaitu aktifitas mencuci tangan yang baik dan benar sesuai dengan pedoman Center for
Disease Control and Preventif 2019 dengan menggunakan sabun. Sehingga di PAUD Cerdas Ceria di Desa Pandansari Kec. Poncokusumo masih perlu ditingkatkan perilaku hidup sehat dan bersih yang merupakan salah satu preventif dan dapat memutus rantai penyebaran berbagai penyakit termasuk virus covid-19. Hal ini merupakan sasaran yang tepat untuk dijadikan obyek pengabdian masyarakat menegenai perilaku hidup bersih dan sehat (PHBS).

Berdasarkan observasi dalam bentuk wawancara kepada 2 orang pendidik dan kurang lebih 20 anak beserta orang tuanya di PAUD Cerdas Ceria di Desa Pandansari Kec. Poncokusumo banyak anak yang belum terbiasa dengan PHBS yang salah satunya yaitu aktifitas mencuci tangan. Mengacu pada hasil observasi tersebut maka Tim PKM menawarkan solusi untuk mengadakan pelatihan mencuci tangan yang baik dan benar sesuai dengan pedoman Center for Disease Control and Preventif 2019 dengan menggunakan sabun cuci tangan. Disamping itu guna menjaga ketersediaan sabun cuci tangan maka juga ditawarkan proses pembuatan sabun cuci tangan yang praktis, digemari siswa dan tetap bermanfaat sebagai antiseptik. Tawaran tersebut disambut gembira dan antusias oleh para pendamping siswa PAUD Cerdas Ceria desa Pandansari Kec. Poncokusumo karena hal tersebut juga bermanfaat untuk memutus rantai penyebaran berbagai penyakit termasuk virus covid-19. Hal ini merupakan sasaran yang tepat untuk dijadikan obyek pengabdian masyarkatat menegenai perilaku hidup bersih dan sehat (PHBS).

\section{METODE}

PKM ini telah dilaksanakan di Desa Pandansari Kec. Poncokusumo Kabupaten Malang Jawa Timur. Mitra dalam kegiatan ini berasal dari Pendamping siswa PAUD Cerdas Ceria yang berjumlah 45 orang. Ada 5 tahapan yang dilakukan dalam kegiatan PKM ini yaitu :

1. Observasi dan pengurusan izin pelaksanaan PKM kepada Kepala Desa dan Ketua PAUD Cerdas Ceria

2. Menyusun jadwal pelaksanaan secara dalam jaringan (daring)

3. Pembuatan video cara membuat sabun cuci tangan dan cara mencuci tangan

4. Sosialisasi dan evaluasi secara daring

5. Pemberian bantuan bahan dan produk sabun cuci tangan

HASIL DAN PEMBAHASAN 
Tahap awal dari pelaksanaan kegiatan PKM ini dalah melakukan observasi untuk memahami keadaan warga yang ada di Desa Pandansari Kec. Poncokusumo Kab. Malang. Observasi dilakukan selama dua hari dengan mendatangi Ahmad Zainul Abidin S.Ag (selaku Kepala Desa), Roikhahnimkmatur (selaku Ketua PAUD) dan perwakilan ibu pendaping dari siswa untuk menentukan waktu, teknis sosialisasi dan jumlah peserta. Tim PKM juga meminta izin kepada Kepala Desa Pandansari untuk melakukan kegiata PKM (Gambar 1). Penyerahan surat perijinan ini bertempat di Pendopo kantor desa Pandansari Ke. Poncokusumo.

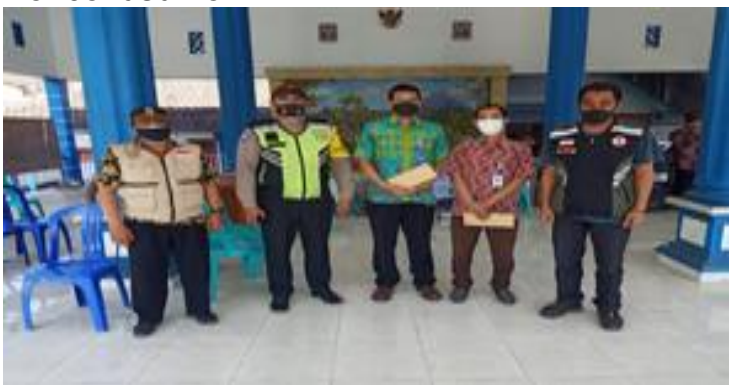

Gambar 1. Penyerahan surat ijin

Tahap kedua dari kegiatan PKM ini adalah menyusun jadwal pelaksanaan (Gambar 2). Berkenaan dalam situasi pandemi maka pelaksanaan dilakukan dalam jaringan (daring) dengan menggunakan media sosial yaitu whatsApp grup. Adapun teknis melakukan sosialisasi dengan membagikan file video yang meliputi video cara pembuatan sabun cuci tangan berbahan aktif lidah buaya (Aloe vera) dan video cara mencuci tangan yang baik dan benar. Video tersebut akan dilihat dan dipahami oleh para pendamping terlebih dahulu.

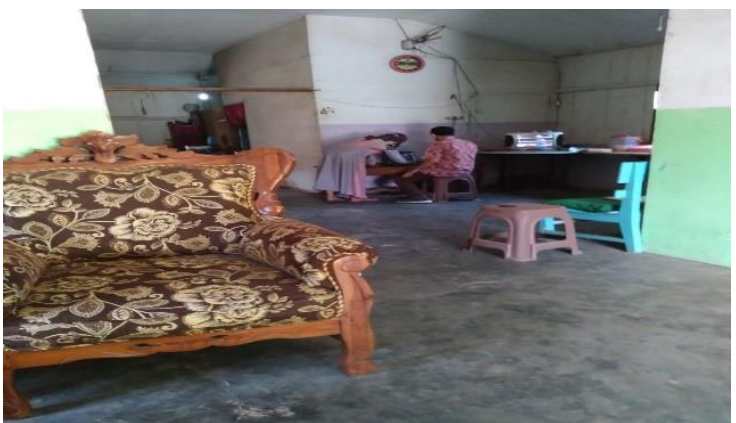

Gambar 2. Penyusunan jadwal

Tahap ketiga dari kegiatan PKM ini adalah pelatihan pembuatan sabun cuci tangan berbahan aktif lidah buaya (Aloe vera) dan cara mencuci tangan dengan baik dan benar. Sebelum dilakukan pelatihan, disiapkan terlebih dahulu bahan dan alat-alat yang diperlukan untuk pembuatan sabun cuci tangan berbahan akttif lidah buaya (Aloe vera). Bahan yang digunakan texapon, sodium sulfat, camperlan, foomboaster, ekstrak lidah buaya, soda asam, benzalkonium chlorid, EDTA, parfum apel dan air. Adapun alat-alat yang digunakan terdiri dari baskom, pengaduk kayu, beker glas, gelas ukur, serbet dan botol penampunng sabun cuci tangan. Setelah seluruh bahan dan alat yang diperlukan sudah siap, maka tim PKM melakukan praktek pembuatan sabun cuci tangan dan didokumentasikan dalm video (Gambar 3). Selanjutnya para pendamping melihat dan mencermati dari tiap tahapan tersebut.

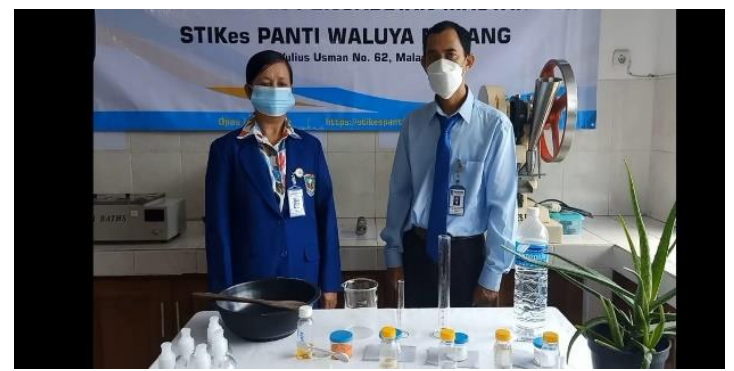

Gambar 3. Pembuatan sabun cuci

Prosedur pembuatan sabun cuci tangan berbahan aktif lidah buaya (Aloe vera) yang dilakukan Tim PKM sebagai berikut :

1) Texapon ditambah sodium sulfat $2 / 3$ aduk sampai rata berwarna putih

2) (1) + masukkan aquadest sedikit demi sedikit sampai ukuran $300 \mathrm{ml}$

3) (2) + camperland aduk rata

4) (3) + tanbahkan $200 \mathrm{ml}$ air aduk rata

5) (4) + sisa sodium sufat aduk rata

6) (5) + soda asam aduk rata + foambooster aduk rata

7) (6) + ekstrak lidah buaya (Aloe vera)

8) (7) + EDTA aduk rata + BKC adujk rata

9) (8) + pewarna secukupnya aduk rata

10) (9) + parfum apael aduk rata

11) Diamkan dan masukkan botol

Sabun cuci tangan berbahan aktif lidah buaya (Aloe vera) yang telah dibuat harus dimasukkan dalam botol dan tertutup rapat (Gambar 4).

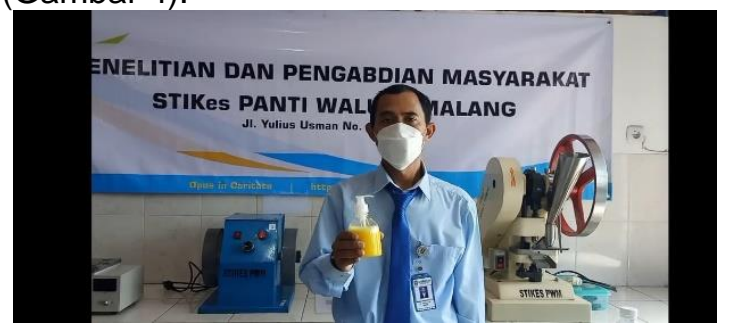

Gambar 4. Produk Sabun cuci tangan

Tahap keempat dari kegiatan PKM ini adalah sosialisasi dan evaluasi melalui dalam jaringan (daring). Kegiatan sosialisasi ini disampaikan pada Ketua PAUD Cerdas Ceria terlebih dahulu yang selanjutnya 
disebarluaskan kepada para pendamping (Gambar 5). Setelah kegiatan sosialisasi dan diskusi melalui dalam jaringan (daring) maka selanjutnya dilakukan evaluasi. Evaluasi ini dilakukan secara post test dengan membagikan lembar quisioner untuk mengetahui pemahaman peserta terhadap materi pelatihan yang telah disampaikan.

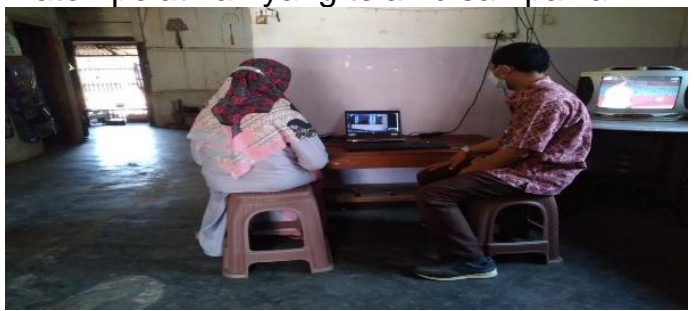

Gambar 5. Sosialisasi dan evaluasi

Evaluasi ini dilakukan untuk melihat apakah ada peningkatan pengetahuan peserta pelatihan terhadap materi pelatihan yang telah dilakukan terkait dengan cara pembuatan sabun cuci tangan berbahan aktif lidah buaya (Aloe vera) dan cara mencuci tangan dengan baik dan benar. Dari hasil post test yang dilakukan hasilnya $84 \%$ (38 peserta) dapat membuat sabun cuci tangan dengan benar dan mengerti cara mencuci tangan seusai dengan prosedur.

Selama pelatihan dilakukan, banyak peserta pelatihan yang mengeluhkan tentang sulitnya memperoleh bahan baku pembuatan sabun cuci tangan berbahan aktif lidah buaya (Aloe vera) dan ketidaktahuan mereka tentang komposisi bahan-bahan yang aman untuk digunakan. Meanggapi permasalahan tersebut, maka pada tahap terakhir dari kegiatan PKM ini dilakukan pemberian bantuan bahan baku dan hasil produk sejumlah 10 liter yang diterima langsung oleh Ketua PAUD Cerdas Ceria dengan rasa syukur dan suka cita (Gambar 6). Mereka sangat terbantu dengan bantuan bahan baku dan hasil produk sabun cuci tangan berbahan aktif lidah buaya (Aloe vera)

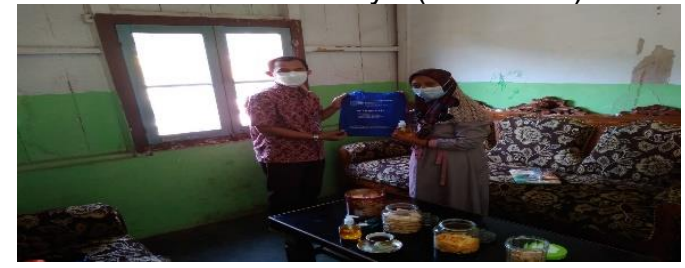

Gambar 6. Penyerahan bantuan bahan dan sabun

\section{SIMPULAN DAN SARAN}

Antusiasme dan rasa ingin tahu dari peserta pelatihan terhadap cara pembuatan sabun cuci tangan berbahan aktif lidah buaya (Aloe vera) dan cara mencuci tangan dengan baik serta benar untuk preventif covid-19 merupakan modal awal yang sangat diperlukan terhadap keberhasilan program PKM yang telah dilakukan. Hal ini terlihat dari evaluasi terhadap kegiatan PKM, dimana pengetahuan peserta pelatihan meningkat setelah dilakukan sosialisasi dan praktek pembuatan sabun cuci tangan berbahan aktif lidah buaya (Aloe vera). Ketua PAUD Cerdas Ceria dan para Ibu siswasiswi PAUD Cerdas Ceria yang merupakan sebagai pendamping diharapkan secara terus menerus dan konsisten mendukung serta memberikan dorongan kepada putra-putrinya agar senantiasa mencuci tangan dengan baik serta benar menggunakan sabun cuci tangan yang telah disediakan.

\section{UCAPAN TERIMA KASIH}

Ucapan terimakasih kami sampaikan kepada LPPM STIKes Panti Waluya Malang, Seluruh pendamping PAUD Cerdas Ceria Desa Pandansari Kec. Poncokusumo Kab. Malang, Para Tokoh Masyarakat Desa Pandansari, Kepala Desa Pandansari beserta staff, masyarakat Desa Pandansari, dan seluruh pihak yang mendukung kegiatan Pengabdian Masyarakat ini.

\section{DAFTAR RUJUKAN}

Arifin, (2011). Pembuatan dan Karakteristik Sabun Cair dengan bahan tambahan Ekstrak Jeruk Nipis (Citrus Aurantifolia S.), Tesis, Program Pascasarjana, Universitas Andalas

Candra, (2009). Kandungan Lidah Buaya, Fakultas Kedokteran Gigi Universitas Indonesia

Dyah Ayu, (2013). Uji Efektivitas Sabun Cair dari Ekstrak Daun Pepaya (Carica Papaya L.) Terhadap Staphylococcus aureus. Skripsi Fakultas Farmasi, Universitas Indonesia Timur Makasar, Makasar.

Funawanthi, (2011). Khasiat dan Manfaat Lidah Buaya. Kanisius. Jakarta

Gusvi Putri et al, (2013). Pembuatan Sabun dengan Lidah Buaya (Aloe Vera) Sebagai Antiseptik Alami (Jurnal Volume 12 No 1). Widya Teknik. Surabaya

Herbeser, (2011). Pengertian Sabun dan Fungsinya. Penebar Swadaya, Jakarta.

Proverawati., dan Rahmawati. (2012). Perilaku Hidup Bersih dan Sehat. Jakarta:Departemen Kesehatan RI

Satrias Apgar, (2010). "Formula Sabun Mandi Cair yang mengandung Gel Daun Lidah Buaya (Aloe vera L.) dengan basis Virginia Coconut Oil (VCO)". Tugas Akhir Sarjana Farmasi, Jurusan Farmasi, FMIPA-Universitas Islam Bandung.

Siswanto, (2010). Mencuci Tangan dengan Sabun, Jakarta: Departemen Kesehatan RI, Jakarta 
Sheila Meitania, (2018). Uji Efektivitas Antibakteri Sediaan Sabun Cair Cuci Tangan Dari Lendir Lidah Buaya (Aloe barbadensis Miller) Terhadap Eschericia coli Dan Staphylococcus aureus STIKes Kharisma Perada, Tangerang 